\title{
The role of non-drug strategies in reducing the risk of cardiovascular complications in women with metabolic syndrome during the menopausal transition
}

\author{
Berikhanova $\mathrm{RR}^{1 *}$, Minenko $\mathrm{IA}^{2}$ and Bondarev $\mathrm{SA}^{3}$ \\ ${ }^{1}$ Federal State Budgetary Institution "Central Clinical Hospital of Civil Aviation”, Moscow, Russia \\ ${ }^{2}$ Department of Integrative Medicine FGAOU VO “First Moscow State Medical University named after I.M. Sechenov”, Moscow, Russia \\ ${ }^{3}$ Cardiologist of the Rehabilitation Clinic of the University Clinical Hospital №2 FGAOU VO "First Moscow State Medical University named after I.M. Sechenov", \\ Moscow, Russia
}

\begin{abstract}
Objective: To study the possibilities of non-drug correction of metabolic and endocrine disorders in women with metabolic syndrome (MS) in menopause. Design: Participants are divided into 5 groups depending on the programs used, each of the groups is divided into 2 subgroups - menopausal syndrome (MPS) of mild to moderate degree.

Setting: Estimated levels of follicle-stimulating (FSH), luteinizing (LH) hormones, estradiol, hemostasis, glycemic status, lipid profiles, Green test.

Participants: 330 women aged 45-50 with menopausal syndrome (MPS) and MS.

Interventions: Standard approach, physical therapy, balneotherapy, multivitamins and minerals, physiotherapy (vibrotherapy, chromotherapy, melotherapy, aromatherapy, aeroionotherapy) in various combinations.

Main outcome measures: Mann-Whitney test, criterion Kruskal-Wallis, Wilcoxon criterion.

Results: In patients with mild MPS, when using programs with physiotherapy, HOMA-IR decreased by $50 \%$, the atherogenic index by more than $25 \%$, the INR level increased by more than $4,0 \%$, the total Green score decreased by more than $40,0 \%$. in patients with moderate MPS, the treatment complex with the simultaneous use of vibrotherapy, chromotherapy, melootherapy, aromatherapy and aeroionotherapy had the advantage: HOMA-IR decreased by 50,5\%, atherogenic index by $30,5 \%$, INR increased by $5,0 \%$, overall score on the Green scale decreased by $40,0 \%$.

Conclusion: In patients with MPS and MS, non-drug programs using physical therapy have a positive effect on the functioning of the endocrine system, hemostasis, carbohydrate and fat metabolism which helps reduce the risk of cardiovascular events. In case of moderate MPS against the background of MS, the program with simultaneous use of vibrotherapy, chromotherapy, melotherapy, aromatherapy and aeroionotherapy has an advantage.
\end{abstract}

\begin{abstract}
Abbreviations: AI: atherogenicity index; BMI: body mass index; IR: insulin resistance; HOMA-IR -Homeostasis Model AssessmentInsulin Resistance; FSH: follicle-stimulating hormone; LH: luteinizing hormone; MHT: menopausal hormone therapy; MPS: menopausal syndrome; MS: metabolic syndrome; TS: total cholesterol; HDL: high-density lipoprotein cholesterol; LDL: low-density lipoprotein cholesterol.
\end{abstract}

\section{Introduction}

The biological process of extinction of reproductive function is associated with the deterioration of physical and mental health, social maladaptation and a decrease in the quality of life of women $[1,2]$. Currently, menopause is a predictor of MS and a high risk of cardiovascular complications [3,4]. An important role in increasing cardiovascular risk is played by thyroid dysfunction, the frequency of which increases in the menopause $[5,6]$. Hormonal restructuring during the menopausal transition creates conditions for the redistribution of the subcutaneous fat layer with its emphasis in the abdominal-visceral region and the formation of MS [7-11]. It is convincingly shown that obesity is a chronic systemic inflammation that triggers insulin resistance (IR), multi-organ metabolic dysfunction, platelet activation, and endothelial stress, which determines a high risk of cardiovascular complications [12-16]. The presence of a woman's metabolic syndrome (MS) exacerbates metabolic and endocrine disorders and subjective symptoms of menopause $[17,18]$. The dominant role of menopausal hormone therapy (MGT) in the treatment of pathological menopause has been established $[19,20]$, but its metabolic and oncological safety remains debatable [21-23]. If there are contraindications to MGT or a woman refuses it, it is a serious problem to provide effective medical

${ }^{*}$ Correspondence to: Berikhanova Rumisa Ramzanovna, Obstetrician Gynecologist, Central Clinical Hospital of Civil Aviation; Applicant, Department of Integrative Medicine, I.M. Sechenov First Moscow State Medical University, Russia, Tel: 89150120906; E-mail: rumiska07@mail.ru

Key words: menopausal syndrome, metabolic syndrome, metabolic and endocrine disorders, cardiovascular risk

Received: July 28, 2020; Accepted: August 03, 2020; Published: August 10, 2020 
Berikhanova RR (2020) The role of non-drug strategies in reducing the risk of cardiovascular complications in women with metabolic syndrome during the menopausal transition

care without the use of estrogen-gestagenic drugs, both from the position of relieving subjective menopausal symptoms, and from the position of preventing cardiovascular complication.

Purpose of work: To study the effect of multimodal non-drug programs for correcting menopausal disorders in patients with metabolic syndrome during the menopausal transition on metabolic and endocrine disorders.

\section{Materials and methods}

Materials: The study, approved by the local ethics Committee of the I. M. Sechenov First Moscow State Medical University, meets international ethical requirements and includes 330 women with infored voluntary consent. By randomization, 5 groups were formed, each of which is divided into two subgroups according to the severity of climacteric syndrome (MPS) on the Greene Climacteric Scale (GCS) [24]: subgroup A - patients with mild MPS (1-11 points), subgroup B patients with moderate MPS (12-19 points) (Table 1$)$.

The age, social characteristics, and somatic status of the groups did not differ. All patients gave voluntary informed consent inclusion criteria: women $45-50$ years old (average age $47.5 \pm 3.5$ years), who are in the period of menopausal transition; the presence of initial MS, diagnosed according to the recommendations of experts of the all-Russian scientific society of cardiologists for the diagnosis and treatment of metabolic syndrome [25], the prescription of MS from two to five years; the presence of mild and moderate MPS, a typical complicated form (against the background of MS); the absence of MGT in the anamnesis; absence of initial disorders of the thyroid gland. Exclusion criteria: whether a woman has: severe mental disorders; alcohol and drug dependence; acute diseases of the cardiovascular system; acute inflammatory diseases; bleeding and propensity to them; malignant or unverified neoplasms; tumors in the growth stage or in a state requiring surgical treatment; signs of severe organ failure; the presence of initially impaired thyroid function according to hormonal examination; the presence of intestinal dysbacteriosis of the 3 degrees of severity; the presence of diabetes mellitus; the presence of vaginitis; individual intolerance to physical factors and / or components of vitamin and mineral products.

Treatment methods: Basic treatment was applied in all groups and included normalization of lifestyle, sleep, diet therapy, and increased physical activity. Treatment principles: personalized approach, timely implementation of events, continuous diet therapy, lifestyle modification (all patients were motivated to quit smoking). In the presence of arterial hypertension, patients received standard antihypertensive therapy (moxonidine $200 \mathrm{mcg}$ orally once a day continuously).
Basic treatment. Reduction diet based on individual calculation of the main exchange: $\mathrm{OO}=(0,0342 \times \mathrm{M}+3,5377) \times 240$, where $\mathrm{OO}$ - the value of the main exchange (kcal), M - body weight $(\mathrm{kg})$. It was recommended to take a fractional meal 5-6 times a day in small portions at the same time. The diet included foods containing complex carbohydrates (cereals, fruits, vegetables), rich in dietary fiber, restricted the use of simple carbohydrates, saturated fat, salt up to $3 \mathrm{~g}$ per day, was not allowed to take coffee, alcohol.

The body mass index (BMI) was calculated using the formula: $\mathrm{BMI}=$ body weight $(\mathrm{kg})$ / body length2 (m2). Food diaries were analyzed. The total energy value of the diet was calculated based on standard caloric coefficients in kcal per 1 gram: $4 \mathrm{kcal}$ for protein and carbohydrates, 7 $\mathrm{kcal}$ for alcohol and $9 \mathrm{kcal}$ for fat.

Physical activity was recommended taking into account the state of health, were in the zone of good tolerance. Used daily walking in the fresh air for 30 minutes. All the patients were motivated to quit smoking, observe the work and rest regime. Basic treatment was carried out in a continuous mode.

Drinking balneotherapy: Ingestion of mineral water "Essentuki № 4 " in the volume of $180-300 \mathrm{ml}$ ( $3 \mathrm{ml}$ per $1 \mathrm{~kg}$ of body weight) at room temperature 30 minutes before meals. The course duration was four weeks, followed by a second course in 3 months.

Therapeutic exercise: We used daily morning hygienic gymnastics for 10-15 minutes, pelvic floor exercise (Kegel exercises), aimed at strengthening the periurethral and perivaginal muscles, anal sphincter, and increasing the functional volume of the bladder [26].

Physiotherapy: The multi-factor physiotherapy unit "Spectra Color SPA System" ("Sybaritic Inc., USA) was used. General vibration therapy: vibration with varying frequency from 10 to $60 \mathrm{~Hz}$ and increasing amplitude up to $7 \mathrm{~mm}$, increasing the frequency of vibration for 8-10 seconds, 15 minutes. Music therapy: relaxing melodies within 30 minutes. Aromatherapy: through a four-channel system, aromatic oils were sprayed inside the capsule: Lavandula officinalis, Foeniculum vulgare. Full spectrum chromotherapy was performed for 30 minutes, with a wavelength from 760 to $400 \mathrm{~nm}$. Selective chromotherapy: green light was applied for 30 minutes, with a wavelength of $530 \mathrm{~nm}$. The face was blown with ionized cool air with a predominance of negative ions for 30 minutes. Inside the capsule, a special individual comfortable microclimate was created. Temperature range $25-30^{\circ} \mathrm{C}$. The contour bed with supporting pads allowed the patient to take the most comfortable and relaxing position. Sessions in the physical therapy facility "Spectra Color SPA System" were held twice a week for 30 minutes, a course of 10 sessions. Repeat the course in 3 months. A total of 20 procedures during observation.

Table 1. Study design

\begin{tabular}{|c|c|c|c|c|c|c|c|c|c|c|}
\hline \multirow{2}{*}{$\begin{array}{c}\text { Group } \\
\text { Sub-group }\end{array}$} & \multicolumn{2}{|c|}{ I } & \multicolumn{2}{|c|}{ II } & \multicolumn{2}{|c|}{ III } & \multicolumn{2}{|c|}{ IV } & \multicolumn{2}{|c|}{$\mathbf{V}$} \\
\hline & IA & IB & IIA & IIB & IIIA & IIIB & IVA & IVB & VA & VB \\
\hline n & 32 & 38 & 30 & 29 & 34 & 32 & 36 & 34 & 38 & 37 \\
\hline 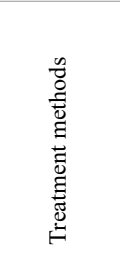 & \multicolumn{2}{|c|}{$\begin{array}{c}\text { Basic treatment } \\
\text { Drinking balneotherapy } \\
\text { Therapeutic exercise } \\
\text { Multivitamins and minerals } \\
\text { Aromatherapy } \\
\text { Ionotherapy } \\
\text { Melotherapy } \\
\text { Vibration therapy } \\
\text { Chromotherapy }\end{array}$} & \multicolumn{2}{|c|}{$\begin{array}{c}\text { Basic treatment } \\
\text { Drinking balneotherapy } \\
\text { Therapeutic exercise } \\
\text { Multivitamins and minerals } \\
\text { Aromatherapy } \\
\text { Ionotherapy } \\
\text { Melotherapy } \\
\text { Vibration therapy }\end{array}$} & \multicolumn{2}{|c|}{$\begin{array}{c}\text { Basic treatment } \\
\text { Drinking balneotherapy } \\
\text { Therapeutic exercise } \\
\text { Multivitamins and minerals } \\
\text { Aromatherapy } \\
\text { Ionotherapy } \\
\text { Melotherapy } \\
\text { Chromotherapy }\end{array}$} & \multicolumn{2}{|c|}{$\begin{array}{c}\text { Basic treatment } \\
\text { Drinking balneotherapy } \\
\text { Therapeutic exercise } \\
\text { Multivitamins and minerals }\end{array}$} & \multicolumn{2}{|c|}{ Basic treatment } \\
\hline
\end{tabular}

Note: subgroup A - mild climacteric syndrome, subgroup B - climacteric syndrome of moderate degree 
Berikhanova RR (2020) The role of non-drug strategies in reducing the risk of cardiovascular complications in women with metabolic syndrome during the menopausal transition

Vitamins and minerals: 22 balanced components ("Menopace " ", " Vitabiotics Ltd., Great Britain) and calcium carbonate with colecalciferol (vitamin D3) (Calcium-D3 Nycomed, Nycomed Pharma, Norway). Menopace " "was taken daily 1 capsule per day during or after meals. The course of treatment is 6 months. "Calcium-D3 nicomed", containing calcium carbonate $1250 \mathrm{mg}$ (equivalent to elementary calcium-500 $\mathrm{mg}$ ) and colecalciferol (vitamin D3) $5 \mathrm{mcg}$ (200 IU), was taken orally 1 tablet 2 times a day for 1 month, repeated course in 3 months. Survey methods:General blood analysis was performed on a hematological analyzer "CELL - DYN 17002 (Abbott, USA). The levels of follicle-stimulating hormone (FSH) and luteinizing hormone ( $\mathrm{LH}$ ) were determined using the automatic enzyme immunoassay "NexGen" ("ADALTIS", Italy) in blood serum using a set of reagents "Alcor Bio" (Russia). The level of estradiol was studied using ELISA's diagnostic ELISA kits (DRG, Germany). The concentration of fibrinogen, APTT (activated partial thromboplastin time), prothrombin time, and thrombin time in blood plasma was studied on the "ACL 9000" coagulograph ("INSTRUMENTATION LABORATORY", USA) using reagents from the same company, and the INR (International Normalized Ratio) was determined using the formula: INR $=$ (patient's Prothrombin time) $/$ Normal average prothrombin time $)^{\mathrm{ISI}}$, where ISI (International Sensitivity Index of thromboplastin) is an indicator of the sensitivity of the used thromboplastin, which standardizes it relative to the international standard. Hagemandependent fibrinolysis was determined (Arkhipov A. G., Eremin G. F., 1985). C-reactive protein (CRP) was determined by the latex immunoturbidimetric method.

A biochemical blood test was performed on an automatic selective biochemical analyzer "Konelab 30" ("Thermo Fisher SCIENTIFIC", Finland) and standard sets of reagents "BioSystems" (Spain), including the determination of glucose, blood lipid spectrum (total cholesterol (TS), high-density lipoprotein cholesterol (HDL), low-density lipoprotein cholesterol (LDL), triglycerides). The atherogenicity index (AI) was determined: $\mathrm{AI}=(\mathrm{TS}-\mathrm{HDL}) / \mathrm{HDL}$; where $\mathrm{AI}$ is the atherogenicity index, $\mathrm{TS}$ is total cholesterol (mmol/l), and HDL is high - density lipoproteins ( $\mathrm{mmol} / \mathrm{l})$.

The concentration of immunoreactive insulin was determined on a microplate reader "Multiscan EX" ("Labsystems", Finland) using reagents from the company " DRG “ (USA). To determine insulin resistance, the HOMA-IR (Homeostasis Model Assessment - Insulin Resistance) model was used. The index is calculated using the formula:

HOMA-IR = fasting glucose $(\mathrm{mmol} / \mathrm{l}) \times$ fasting insulin $(\mathrm{Mme} / \mathrm{l})$ /22.5 (Matthews D. R., 1985).

\section{Statistical analysis}

The sample size was not calculated beforehand. Statistical data processing was performed using the application software packages Statistica 10 ("StatSoft Inc", USA) and SAS JMP 11 ("SAS", USA). Comparisons of the two groups on quantitative scales were made based on the nonparametric Mann-Whitney test. Comparing three or more groups on the quantitative scales were based on nonparametric criterion Kruskal-Wallis. To describe quantitative indicators, the average value and standard deviation in the format " $\mathrm{M} \pm \sigma$ "were used. The analysis of dynamics of indicators in the case of comparison of two periods was performed on the basis of nonparametric Wilcoxon criterion. The level of statistical significance was determined at the error probability level of 0,05 .

\section{Result}

The results of the study: Hormonal profile: It was found that in women with moderate MPS in the period of early menopausal transition, the levels of FSH and LH were higher, and the level of estradiol was lower compared to the corresponding indicators of women with mild MPS, which indicated more pronounced violations of the hypothalamic-pituitary-ovarian axis.

Among patients with mild MPS, the most significant positive changes in the hormonal background were found when using complexes with physiotherapy (complexes I, II and III), which was expressed in a significant decrease in gonadotropins after 3 months of treatment, a significant increase in estradiol. The FSH level is shown in table 2 (Table 2)

The level of FSH decreased in patients of subgroup IA after 3 months of therapy by $11,9 \%(\mathrm{p}=0,0183)$, and after 6 months of treatment by $23,2 \%(p<0,0001)$, respectively in subgroup IIA - by $10,7 \%(p=0,0208)$ and $20.3 \%(\mathrm{p}<0,0001)$, in subgroup IIIA by $10,4 \%(\mathrm{p}=0,0162)$ and $19,1 \%$ $(\mathrm{p}<0,0001)$. Significant regression of FSH was also found in the IVA subgroup - by $6,0 \%(p=0,0227)$ and $14,0 \%(p<0,0001)$, respectively, but there were statistically significant differences with the IA subgroup. In the VA subgroup, the level of FSH did not change significantly, but there was a tendency for it to increase. Among patients with moderate MPS, the most significant decrease in FSH was observed in subgroups IB, IIB and IIIB: in subgroup IB after 3 months by $11,6 \%(p=0,0237)$, after 6 months of treatment by $19,3 \%(\mathrm{p}<0,0001)$, respectively in subgroup IIB by $8,8 \%(p=0,0222)$ and $17,6 \%(p<0,0001)$, in subgroup IIIB by $8,6 \%(p=0,0183)$ and $16,5 \%(p<0,0001)$. In subgroup IVB, the level of FSH significantly decreased after 6 months of treatment by $12.0 \%$ ( $\mathrm{p}<0.0001$ ), but was significantly lower compared to the corresponding indicator in subgroup IB. Attention was focused on a significant increase in the level of FSH in the VB subgroup - by $2,6 \%(p=0,0008)$.

Table 2. Dynamics of follicle-stimulating hormone $(\mathrm{mMe} / \mathrm{ml})$ levels

\begin{tabular}{|c|c|c|c|c|c|}
\hline Subgroup & $\begin{array}{l}\mathrm{M} \pm \mathrm{S} \\
\text { before }\end{array}$ & $\begin{array}{c}\mathrm{M} \pm \mathrm{S} \\
3 \text { months }\end{array}$ & $\begin{array}{c}\mathrm{M} \pm \mathrm{S} \\
6 \text { months }\end{array}$ & $\begin{array}{c}\text { P } \\
\text { (before - } 3 \text { months) }\end{array}$ & $\begin{array}{c}P \\
\text { (before }-6 \text { months) }\end{array}$ \\
\hline IA & $66,92 \pm 30,50$ & $58,98 \pm 31,67$ & $51,41 \pm 31,78$ & 0,0183 & $<0,0001$ \\
\hline IIA & $64,57 \pm 30,30$ & $57,65 \pm 31,84$ & $51,43 \pm 31,34$ & 0,0208 & $<0,0001$ \\
\hline IIIA & $66,88 \pm 30,67$ & $59,90 \pm 32,50$ & $54,08 \pm 31,29$ & 0,0162 & $<0,0001$ \\
\hline IVA & $68,76 \pm 30,73$ & $64,66 \pm 31,28$ & $59,15 \pm 29,57$ & 0,0227 & $<0,0001$ \\
\hline VA & $67,70 \pm 30,33$ & $68,26 \pm 32,70$ & $70,26 \pm 35,23$ & 0,5534 & 0,9273 \\
\hline IB & $88,80 \pm 32,38$ & $78,47 \pm 31,96$ & $71,67 \pm 31,69$ & 0,0237 & $<0,0001$ \\
\hline IIB & $85,10 \pm 33,21$ & $77,61 \pm 31,32$ & $70,12 \pm 30,49$ & 0,0222 & $<0,0001$ \\
\hline IIIB & $83,55 \pm 32,04$ & $76,36 \pm 30,55$ & $69,75 \pm 30,51$ & 0,0183 & $<0,0001$ \\
\hline IVB & $83,38 \pm 31,93$ & $80,67 \pm 32,73$ & $73,39 \pm 31,32$ & 0,0610 & $<0,0001$ \\
\hline VB & $82,64 \pm 31,81$ & $83,23 \pm 32,47$ & $84,82 \pm 33,31$ & 0,9875 & 0,0008 \\
\hline
\end{tabular}


Berikhanova RR (2020) The role of non-drug strategies in reducing the risk of cardiovascular complications in women with metabolic syndrome during the menopausal transition

The LH level is shown in table 3. Significant regression was observed in subgroup IA, after 3 months of treatment by 19,6\% ( $\mathrm{p}=0,0109)$, after 6 months of treatment by $25,6 \%$, in subgroup IIA by $18,4 \%(\mathrm{p}=0,0069)$ and $25,0 \%(\mathrm{p}<0,0001)$, in subgroup IIIA by $17,1 \%(\mathrm{p}=0,0127)$ and $23,0 \%(p<0,0001)$, respectively, differences between subgroups were not significant (Table 3 ).

In the IVA subgroup, a statistically significant regression of $\mathrm{LH}$ was detected after 6 months of treatment - by $11,7 \%(p<0,0001)$, but the indicator significantly differed from that of the IA subgroup. It is important to note that in the VA subgroup, the LH level significantly increased by $12.2 \%(\mathrm{p}<0,0001)$. Among patients with moderate MPS after 3 months of treatment, only the IB subgroup showed a significant decrease in the level of $\mathrm{LH}$ - by $16,3 \%(\mathrm{p}=0,0181)$. After 6 months, the regression of the LH level in subgroup IB reached $23,9 \%(\mathrm{p}<0,0001)$, and there was a significant decrease in the indicator in subgroups IIB, IIIB - by $19,4 \%(\mathrm{p}<0.0001), 20,0 \%(\mathrm{p}<0,0001)$, respectively, and to a lesser extent in subgroup IIIB - by $4,0 \%(\mathrm{p}=0,0404)$. Attention was drawn to a statistically significant increase in the level of $\mathrm{LH}$ in the VB subgroup by $7,4 \%(\mathrm{p}<0,0001)$.
Table 4 shows the level of estradiol. A significant increase in estradiol was detected after 6 months of treatment in subgroups IA, IIA, IIIA and IVA-by $22,3 \%(\mathrm{p}=0,0084), 18,1 \%(\mathrm{p}=0,0208), 18,3 \%(\mathrm{p}=0,0005)$ and $11,1 \%(\mathrm{p}=0,0113)$, respectively (Table 4$)$.

However, there were no significant differences between these subgroups. There was no significant change in the level of estradiol in the VA subgroup, the indicator significantly differed from the indicator in the IA subgroup.

In patients with moderate MPS, there was an increase in the level of estradiol in subgroups IB, IIB, IIIB and IVB, it was not reliable. There was a decrease in the level of estradiol in the VB subgroup, but it was not statistically significant (Table 5 ).

Body Mass Index: BMI is shown in table 5. Initially, the average BMI in subgroups A was $36,07 \pm 0,89$, in subgroups $B$ it was significantly higher $-36,48 \pm 0,99(\mathrm{p}=0,0045)$. In patients with mild MPS, BMI regression was $11,8 \%(\mathrm{p}=0,0109)$ in subgroup IA after 3 months of treatment, $17,0 \%(\mathrm{p}<0.0001)$ after 6 months of treatment, $11,1 \%(\mathrm{p}=0,0183)$ and $15.3 \%(\mathrm{p}<0,0001)$ in subgroup IIIA, $9,2 \%$

Table 3. Dynamics of luteinizing hormone level $(\mathrm{mMe} / \mathrm{ml})$

\begin{tabular}{|c|c|c|c|c|c|}
\hline Subgroup & $\begin{array}{l}\mathbf{M} \pm \mathrm{S} \\
\text { before }\end{array}$ & $\begin{array}{c}\mathrm{M} \pm \mathrm{S} \\
3 \text { months }\end{array}$ & $\begin{array}{c}\mathrm{M} \pm \mathrm{S} \\
6 \text { months }\end{array}$ & $\begin{array}{c}\text { P } \\
\text { (before }-3 \text { months) }\end{array}$ & $\begin{array}{c}\text { P } \\
\text { (before }-6 \text { months) }\end{array}$ \\
\hline IA & $23,87 \pm 5,93$ & $19,19 \pm 6,71$ & $17,76 \pm 6,12$ & 0,0109 & $<0,0001$ \\
\hline IIA & $23,47 \pm 5,49$ & $19,15 \pm 6,83$ & $17,61 \pm 6,44$ & 0,0069 & $<0,0001$ \\
\hline IIIA & $23,49 \pm 6,02$ & $19,48 \pm 6,75$ & $18,10 \pm 6,25$ & 0,0127 & $<0,0001$ \\
\hline IVA & $24,53 \pm 5,92$ & $23,39 \pm 5,51$ & $21,65 \pm 5,99$ & 0,0525 & $<0,0001$ \\
\hline VA & $24,47 \pm 5,72$ & $25,39 \pm 5,61$ & $27,45 \pm 4,70$ & 0,0938 & $<0,0001$ \\
\hline IB & $29,84 \pm 6,01$ & $24,97 \pm 7,43$ & $22,70 \pm 8,17$ & 0,0181 & $<0,0001$ \\
\hline IIB & $29,04 \pm 5,50$ & $26,39 \pm 7,48$ & $23,39 \pm 8,33$ & 0,1358 & $<0,0001$ \\
\hline IIIB & $28,41 \pm 5,75$ & $26,41 \pm 7,00$ & $22,74 \pm 8,07$ & 0,1054 & $<0,0001$ \\
\hline IVB & $27,97 \pm 6,02$ & $27,42 \pm 6,49$ & $26,85 \pm 5,39$ & 0,2074 & 0,0404 \\
\hline VB & $28,27 \pm 5,58$ & $28,71 \pm 6,08$ & $30,37 \pm 5,09$ & 0,3613 & $<0,0001$ \\
\hline
\end{tabular}

Table 4. Dynamics of estradiol level (pmol / 1)

\begin{tabular}{|c|c|c|c|c|c|}
\hline Subgroup & $\begin{array}{l}\mathrm{M} \pm \mathrm{S} \\
\text { before }\end{array}$ & $\begin{array}{c}\mathrm{M} \pm \mathrm{S} \\
3 \text { months }\end{array}$ & $\begin{array}{c}\mathrm{M} \pm \mathrm{S} \\
\mathbf{6} \text { months }\end{array}$ & $\begin{array}{c}\text { P } \\
\text { (before - } \mathbf{3} \text { months) }\end{array}$ & $\begin{array}{c}P \\
\text { (before - } 6 \text { months) }\end{array}$ \\
\hline IA & $113,83 \pm 53,71$ & $126,04 \pm 65,67$ & $139,17 \pm 77,87$ & 0,5168 & 0,0084 \\
\hline IIA & $119,28 \pm 54,66$ & $125,48 \pm 60,31$ & $140,86 \pm 73,85$ & 0,7057 & 0,0208 \\
\hline IIIA & $114,07 \pm 54,65$ & $119,33 \pm 59,40$ & $134,88 \pm 73,78$ & 0,2401 & 0,0005 \\
\hline IVA & $112,18 \pm 52,94$ & $114,19 \pm 54,73$ & $124,59 \pm 64,78$ & 0,8110 & 0,0113 \\
\hline VA & $115,18 \pm 55,82$ & $115,42 \pm 56,26$ & $118,69 \pm 59,59$ & 0,8625 & 0,7394 \\
\hline IB & $83,88 \pm 34,03$ & $90,10 \pm 41,12$ & $93,06 \pm 43,79$ & 0,7368 & 0,0993 \\
\hline IIB & $88,55 \pm 35,03$ & $92,23 \pm 38,49$ & $94,65 \pm 41,14$ & 0,5782 & 0,1950 \\
\hline IIIB & $91,20 \pm 36,45$ & $94,34 \pm 39,50$ & $98,25 \pm 43,29$ & 0,8688 & 0,1786 \\
\hline IVB & $90,29 \pm 34,78$ & $92,31 \pm 36,92$ & $94,66 \pm 39,16$ & 0,7959 & 0,2759 \\
\hline VB & $90,76 \pm 35,09$ & $88,63 \pm 32,89$ & $88,08 \pm 33,16$ & 0,4932 & 0,1012 \\
\hline
\end{tabular}

Table 5. Dynamics of body mass index (BMI)

\begin{tabular}{|c|c|c|c|c|c|}
\hline Subgroup & $\begin{array}{l}\mathbf{M} \pm \mathbf{S} \\
\text { Before }\end{array}$ & $\begin{array}{c}\mathrm{M} \pm \mathrm{S} \\
3 \text { months }\end{array}$ & $\begin{array}{c}\mathrm{M} \pm \mathrm{S} \\
6 \text { months }\end{array}$ & $\begin{array}{c}\text { P } \\
\text { Before - } 3 \text { months }\end{array}$ & $\begin{array}{c}\text { P } \\
\text { Before }-6 \text { months }\end{array}$ \\
\hline IA & $36,15 \pm 1,02$ & $31,88 \pm 1,98$ & $29,99 \pm 1,78$ & 0,0109 & $<0,0001$ \\
\hline IIA & $36,14 \pm 0,90$ & $32,13 \pm 2,28$ & $30,61 \pm 2,19$ & 0,0183 & $<0,0001$ \\
\hline IIIA & $35,99 \pm 0,84$ & $32,68 \pm 2,38$ & $30,80 \pm 2,39$ & 0,0449 & $<0,0001$ \\
\hline IVA & $36,08 \pm 0,77$ & $33,12 \pm 2,28$ & $31,75 \pm 2,28$ & 0,0525 & $<0,0001$ \\
\hline VA & $35,98 \pm 0,91$ & $34,33 \pm 2,55$ & $34,39 \pm 2,32$ & 0,1300 & 0,0723 \\
\hline IB & $36,45 \pm 0,79$ & $32,73 \pm 1,58$ & $30,88 \pm 1,66$ & 0,0136 & $<0,0001$ \\
\hline IIB & $36,50 \pm 1,15$ & $32,93 \pm 2,14$ & $31,17 \pm 1,52$ & 0,0129 & $<0,0001$ \\
\hline IIIB & $36,46 \pm 0,93$ & $32,89 \pm 1,80$ & $31,42 \pm 1,82$ & 0,0109 & $<0,0001$ \\
\hline IVB & $36,51 \pm 1,15$ & $33,08 \pm 2,10$ & $31,88 \pm 2,61$ & 0,0112 & $<0,0001$ \\
\hline VB & $36,48 \pm 0,93$ & $35,78 \pm 1,94$ & $35,16 \pm 1,97$ & 0,7304 & 0,0929 \\
\hline
\end{tabular}


Berikhanova RR (2020) The role of non-drug strategies in reducing the risk of cardiovascular complications in women with metabolic syndrome during the menopausal transition

$(\mathrm{p}=0,0449)$ and $14.4 \%(\mathrm{p}<0,0001)$ in subgroup IVA, $8.2 \%(\mathrm{p}=0,0525)$ and $12,0 \%(\mathrm{p}<0,0001)$. The lowest BMI regression was observed in the VA subgroup: after 3 months of treatment by $4,6 \%(p=0,1300)$, after 6 months of treatment by $4,4 \%(\mathrm{p}=0,0723)$. In patients with moderate MPS, BMI reduction was: in subgroup IB after 3 months of treatment, $10,2 \%(\mathrm{p}=0,0136)$, after 6 months of treatment, 15,3\% ( $\mathrm{p}<0.0001)$, respectively in subgroup IIB, 9,6\% $(\mathrm{p}=0,0129)$ and $14,6 \%(\mathrm{p}<0,0001)$, in subgroup IIIB $-9,8 \%(p=0,0109)$ and $13,8 \%(p<0,0001)$, in subgroup IVB $-9,4 \%(p=0,0112)$ and $12,7 \%(p<0,0001)$. In the VB subgroup, the decrease in BMI was not significant - by $1,9 \%(\mathrm{p}=0,7304)$ and $3,6 \%$ ( $\mathrm{p}=0,0929)$, respectively.

Hemostasis: It was found that in patients with moderate MPS, the thrombophilic properties of blood were more pronounced compared to patients with mild MPS, as indicated by lower values of INR, APTT, higher platelet levels, and XIIA -dependent fibrinolysis.

In patients with mild MPS, the number of platelets (Table 6) significantly decreased after 3 months of treatment in subgroups IA and IIA - by $4,24 \%(\mathrm{p}=0,0048)$ and $3,83 \%(\mathrm{p}=0,0005)$, respectively, and after 6 months of treatment, there was a significant regression of the indicator in subgroups IA, IIA and IIIA - by $5,41 \%$ ( $<<0,0001), 4,11 \%$ $(\mathrm{p}<0.0001)$ and $1,79 \%(\mathrm{p}=0,0008)$, respectively. No significant changes were found in subgroups IVA and VA. Among patients with moderate $\mathrm{CS}$, a significant decrease in the number of trombocytes was found after 3 months of treatment only in subgroup IB by 1,23\%, and after 6 months of treatment-in subgroups IB and IIB - by $2,17 \%(\mathrm{p}=0.0127)$ and $1,04 \%$ $(\mathrm{p}=0,0222)$, respectively. In subgroups IIIB and IVB, the indicator did not change significantly. There was a slight increase in the number of platelets in the VB subgroup, but it was not reliable.

A significant increase in the level of INR relative to the baseline was observed in subgroup IA after 3 months of treatment by 4,0 $\%(p=0,0142)$, after 6 months of treatment by $5,0 \%(p=0,0041)$. In subgroups IIA and IIIA, a statistically significant decrease in INR was achieved after 6 months of treatment by $4,0 \%(p=0,0028)$ and $4,0 \%(p=0,0206)$, respectively. Among patients with moderate MPS, a significant increase in INR was recorded only in subgroup IB after 6 months of treatment - by $5,1 \%(\mathrm{p}=0,0157)$. In both subgroups of group IV, the level of INR increased slightly, but not significantly relative to the baseline. There was also no significant change in the level of INR in both subgroups of group V (Table 7). At the same time, the indicators significantly differed from similar indicators in group I.

The dynamics of the APTT level is shown in table 8. In patients of subgroups IA, IIA and IIIA, APTT significantly increased after 3 months of treatment - by $1,8 \%(\mathrm{p}=0,0183), 1,5 \%(\mathrm{p}=0,0303)$ and $1,1 \%(\mathrm{p}=0,0231)$, respectively, after 6 months of treatment - by $3,2 \%$ $(\mathrm{p}<0,0001), 2,7 \%(\mathrm{p}<0,0001)$ and $2,3 \%(\mathrm{p}<0,0001)$, the differences between the subgroups were not statistically significant. In the IVA subgroup, the APTT index significantly increased after 6 months of treatment by $0,8 \%(\mathrm{p}=0,0036)$. Among patients with moderate MPS, APTT significantly increased after 3 months of treatment in subgroups IB and IIB by $1,6 \%(p=0,0271)$ and $0,9 \%(p=0,0062)$, respectively. After 6 months of therapy, there was an increase in APTT in subgroup IB by $3,3 \%(\mathrm{p}<0,0001)$, in subgroup IIB by $1,2 \%(\mathrm{p}=0,0002)$, and in subgroup IIIB by $1,1 \%(p=0,0063)$. In subgroup IVB, the level of APTT increased by $0,9 \%$ after 3 months of treatment $(\mathrm{p}=0,0112)$, but after 6 months the indicator did not significantly differ from the initial one. In both subgroups of group V, there were no significant changes in APTT (Table 8).

Initially, there was an inhibition of the activity of the fibrinolytic system in patients with MPS on the background of MS, and more pronounced in patients with moderate MPS compared to patients with mild MPS. The level of XIIA-dependent fibrinolysis is shown in table 9. After 3 months of treatment, the level of XIIA-dependent fibrinolysis significantly decreased in subgroup IA by $13,5 \%(\mathrm{p}=0,0234)$. After 6 months, a statistically significant decrease was observed in subgroups

Table 6. Analysis of the dynamics of the indicator "Platelets, $\mathrm{x} 10^{3} / \mathrm{mm}^{3}$ »

\begin{tabular}{|c|c|c|c|c|c|}
\hline Subgroup & $\begin{array}{l}\mathbf{M} \pm \mathbf{S} \\
\text { Before }\end{array}$ & $\begin{array}{c}\mathrm{M} \pm \mathrm{S} \\
3 \text { months }\end{array}$ & $\begin{array}{c}\mathrm{M} \pm \mathrm{S} \\
6 \text { months }\end{array}$ & $\begin{array}{c}\text { P } \\
\text { Before }-\mathbf{3} \text { months }\end{array}$ & $\begin{array}{c}\text { P } \\
\text { Before }-6 \text { months }\end{array}$ \\
\hline IA & $285,96 \pm 2,06$ & $273,84 \pm 2,27$ & $270,50 \pm 2,66$ & 0,0048 & $<0,0001$ \\
\hline IIA & $284,72 \pm 2,66$ & $273,82 \pm 2,61$ & $273,02 \pm 2,43$ & 0,0005 & $<0,0001$ \\
\hline IIIA & $285,63 \pm 2,97$ & $284,38 \pm 2,57$ & $280,49 \pm 2,35$ & 0,4788 & 0,0008 \\
\hline IVA & $286,79 \pm 2,29$ & $284,89 \pm 3,00$ & $284,24 \pm 2,34$ & 0,1395 & 0,0762 \\
\hline VA & $285,13 \pm 2,66$ & $284,03 \pm 2,50$ & $284,07 \pm 2,66$ & 0,7831 & 0,6475 \\
\hline IB & $286,26 \pm 2,61$ & $282,75 \pm 2,78$ & $280,05 \pm 2,17$ & 0,0207 & 0,0127 \\
\hline IIB & $287,80 \pm 2,24$ & $285,39 \pm 2,58$ & $284,82 \pm 2,11$ & 0,1118 & 0,0222 \\
\hline IIIB & $285,01 \pm 2,24$ & $284,38 \pm 2,85$ & $284,08 \pm 2,18$ & 0,9394 & 0,3679 \\
\hline IVB & $287,08 \pm 3,33$ & $286,12 \pm 2,65$ & $284,55 \pm 2,74$ & 0,7000 & 0,0897 \\
\hline VB & $285,84 \pm 2,76$ & $287,74 \pm 2,77$ & $288,23 \pm 2,32$ & 0,0327 & 0,0170 \\
\hline
\end{tabular}

Table 7. Dynamics of INR level $(0,84-1,15)$

\begin{tabular}{|c|c|c|c|c|c|}
\hline Subgroup & $\begin{array}{l}\mathbf{M} \pm \mathbf{S} \\
\text { Before }\end{array}$ & $\begin{array}{c}\mathrm{M} \pm \mathrm{S} \\
3 \text { months }\end{array}$ & $\begin{array}{c}\mathrm{M} \pm \mathrm{S} \\
6 \text { months }\end{array}$ & $\begin{array}{c}\text { P } \\
\text { Before }-3 \text { months }\end{array}$ & $\begin{array}{c}\text { P } \\
\text { Before }-6 \text { months }\end{array}$ \\
\hline IA & $1,00 \pm 0,02$ & $1,04 \pm 0,03$ & $1,05 \pm 0,03$ & 0,0142 & 0,0041 \\
\hline IIA & $0,99 \pm 0,03$ & $1,01 \pm 0,03$ & $1,03 \pm 0,03$ & 0,2883 & 0,0028 \\
\hline IIIA & $0,99 \pm 0,04$ & $1,02 \pm 0,03$ & $1,03 \pm 0,04$ & 0,2074 & 0,0206 \\
\hline IVA & $1,01 \pm 0,04$ & $1,01 \pm 0,04$ & $1,02 \pm 0,03$ & 0,8518 & 0,0841 \\
\hline VA & $0,99 \pm 0,03$ & $0,97 \pm 0,03$ & $0,99 \pm 0,03$ & 0,2642 & 0,9407 \\
\hline IB & $0,97 \pm 0,04$ & $1,00 \pm 0,03$ & $1,02 \pm 0,03$ & 0,3924 & 0,0157 \\
\hline IIB & $0,97 \pm 0,04$ & $0,99 \pm 0,03$ & $0,99 \pm 0,02$ & 0,2915 & 0,4382 \\
\hline IIIB & $0,97 \pm 0,02$ & $1,01 \pm 0,03$ & $1,00 \pm 0,03$ & 0,0580 & 0,1054 \\
\hline IVB & $0,98 \pm 0,02$ & $0,99 \pm 0,03$ & $1,00 \pm 0,03$ & 0,3787 & 0,3149 \\
\hline VB & $0,98 \pm 0,03$ & $0,99 \pm 0,04$ & $0,98 \pm 0,03$ & 0,5641 & 0,9384 \\
\hline
\end{tabular}


Berikhanova RR (2020) The role of non-drug strategies in reducing the risk of cardiovascular complications in women with metabolic syndrome during the menopausal transition

IA, IIA, and IIIA: $21,3 \%(\mathrm{p}=0,0001), 14,4 \%(\mathrm{p}=0,0014)$, and $17,7 \%$ $(\mathrm{p}=0,0019)$, respectively. It should be noted that the differences between these subgroups were not statistically significant. In the IVA subgroup after 6 months, the level of XIIA-dependent fibrinolysis significantly decreased by $9,8 \%(p=0,0350)$, but the indicator was significantly higher in comparison with the IA subgroup.

Among subgroups of patients with moderate MPS, the level of XIIA-dependent fibrinolysis significantly decreased after 6 months of treatment in subgroups IB, IIB, IIIB and IVB - by $18,3 \%(\mathrm{p}=0,0470)$, $16,1 \%(p=0,0053), 16,5 \%(p=0,0014)$ and $12,8 \%(p=0,0325)$, while no significant differences were found between the subgroups. In both subgroups of group V, there was no statistically significant change in the level of XIIA-dependent fibrinolysis.

Significant regression of fibrinogen was recorded after 6 months of treatment in both subgroups of all groups (Table 10). Markers of inflammation: The most pronounced decrease in fibrinogen levels was observed in subgroups IA, IIA and IIIA, respectively, by $17,1 \%$ $(\mathrm{p}<0,0001), 14,6 \%(\mathrm{p}<0,0001)$ and $12,2 \%(\mathrm{p}<0,0001)$, in subgroups
IB, IIB and IIIB, respectively, by $16,3 \%(\mathrm{p}<0,0001), 11,6 \%(\mathrm{p}<0,0001)$ and $11,6 \%(p<0,0001)$. When comparing indicators between similar subgroups of groups I, II and III, no statistically significant differences were found. In the IVA subgroup, the level of fibrinogen significantly decreased after 6 months of treatment by $9,8 \%(p=0,0005)$, in the IVB subgroup by $7,1 \%(p<0,0001)$. The VA and VB subgroups did not show a statistically convincing decrease in fibrinogen levels. It is noteworthy that the indicators in groups IV and V significantly differed from those in group I. among patients with mild MPS, the level of CRP significantly decreased after 6 months of treatment in all groups (Table 11).

The most pronounced regression of CRP was observed after 6 months of treatment in groups I, II and III: in subgroups IA, IIA and IIIA: respectively by $18,2 \%(\mathrm{p}<0,0001), 14,4 \%(\mathrm{p}=0,0014)$ and $14,2 \%$ ( $\mathrm{p}=0,0038)$, in subgroups IB, IIB and IIIB - by $17,8 \%(\mathrm{p}=0,0008), 16,2 \%$ $(\mathrm{p}=0,0001)$ and $15,2 \%(\mathrm{p}=0,0048)$. In the IVA and IVB subgroups, there was also a statistically significant decrease in CRP after 6 months of treatment - by $9,2 \%(\mathrm{p}=0,0089)$ and $9,9 \%(\mathrm{p}=0,0066)$, respectively, while in these subgroups, the level of CRP was significantly higher against the same subgroups of group I. In subgroup VA, the level of

Table 8. Dynamics of the level of APTT, sec $(24,0-35,0 \mathrm{sec})$

\begin{tabular}{|c|c|c|c|c|}
\hline Subgroup & $\begin{array}{c}\mathbf{M} \pm \mathbf{S}, \\
\text { Before }\end{array}$ & $\begin{array}{c}\mathbf{M} \pm \mathbf{S}, \\
\mathbf{3} \text { months }\end{array}$ & $\begin{array}{c}\mathbf{M} \pm \mathbf{S}, \\
\mathbf{6} \text { months }\end{array}$ & $\begin{array}{c}\mathbf{P} \\
\text { Before }-\mathbf{6} \text { months }\end{array}$ \\
\hline IA & $26,86 \pm 0,14$ & $27,34 \pm 0,13$ & $27,71 \pm 0,15$ & 0,0183 \\
\hline IIA & $26,81 \pm 0,17$ & $27,21 \pm 0,16$ & $27,52 \pm 0,16$ & 0,0303 \\
\hline IIIA & $27,00 \pm 0,13$ & $27,30 \pm 0,17$ & $27,62 \pm 0,16$ & 0,0231 \\
\hline IVA & $27,01 \pm 0,12$ & $27,04 \pm 0,17$ & $27,21 \pm 0,16$ & 0,6729 \\
\hline VA & $26,90 \pm 0,19$ & $26,86 \pm 0,15$ & $27,02 \pm 0,17$ & 0,7394 \\
\hline IB & $25,11 \pm 0,17$ & $25,51 \pm 0,13$ & $25,94 \pm 0,13$ & 0,0271 \\
\hline IIB & $25,31 \pm 0,13$ & $25,54 \pm 0,14$ & $25,60 \pm 0,16$ & 0,0001 \\
\hline IIIB & $25,21 \pm 0,18$ & $25,30 \pm 0,14$ & $25,49 \pm 0,15$ & 0,0062 \\
\hline IVB & $25,31 \pm 0,18$ & $25,54 \pm 0,13$ & $25,48 \pm 0,17$ & 0,6501 \\
\hline VB & $25,14 \pm 0,19$ & $25,02 \pm 0,15$ & $24,99 \pm 0,15$ & 0,0001 \\
\hline
\end{tabular}

Table 9. Dynamics of the level of XIIA-dependent fibrinolysis, $\min (5-12 \mathrm{~min})$

\begin{tabular}{|c|c|c|c|c|c|}
\hline Subgroup & $\begin{array}{l}\mathbf{M} \pm \mathbf{S} \\
\text { Before }\end{array}$ & $\begin{array}{c}\mathrm{M} \pm \mathrm{S} \\
3 \text { months }\end{array}$ & $\begin{array}{c}\mathrm{M} \pm \mathrm{S} \\
6 \text { months }\end{array}$ & $\begin{array}{c}\text { P } \\
\text { Before - } 3 \text { months }\end{array}$ & $\begin{array}{c}\text { P } \\
\text { Before }-6 \text { months }\end{array}$ \\
\hline IA & $11,16 \pm 0,88$ & $9,66 \pm 1,21$ & $8,78 \pm 0,66$ & 0,0234 & 0,0001 \\
\hline IIA & $11,10 \pm 0,99$ & $10,50 \pm 0,78$ & $9,50 \pm 0,82$ & 0,4564 & 0,0014 \\
\hline IIIA & $11,15 \pm 1,21$ & $9,94 \pm 1,28$ & $9,18 \pm 1,00$ & 0,0743 & 0,0019 \\
\hline IVA & $11,03 \pm 1,03$ & $10,61 \pm 0,96$ & $9,94 \pm 1,17$ & 0,6486 & 0,0350 \\
\hline VA & $11,24 \pm 0,91$ & $10,79 \pm 1,02$ & $10,61 \pm 0,82$ & 0,5534 & 0,1516 \\
\hline IB & $11,27 \pm 1,12$ & $9,95 \pm 1,08$ & $9,21 \pm 1,07$ & 0,3666 & 0,0470 \\
\hline IIB & $11,21 \pm 1,18$ & $10,03 \pm 0,82$ & $9,41 \pm 1,15$ & 0,1233 & 0,0053 \\
\hline IIIB & $11,19 \pm 1,15$ & $10,31 \pm 1,03$ & $9,34 \pm 0,90$ & 0,2441 & 0,0014 \\
\hline IVB & $11,26 \pm 0,90$ & $10,71 \pm 1,06$ & $9,82 \pm 1,29$ & 0,7959 & 0,0325 \\
\hline VB & $11,14 \pm 1,18$ & $11,00 \pm 0,82$ & $10,97 \pm 0,96$ & 0,7969 & 0,9245 \\
\hline
\end{tabular}

Table 10. Dynamics of fibrinogen level, g/l (2.0-4.0 g / 1)

\begin{tabular}{|c|c|c|c|c|c|}
\hline Subgroup & $\begin{array}{l}\mathrm{M} \pm \mathrm{S} \\
\text { Before }\end{array}$ & $\begin{array}{c}\mathrm{M} \pm \mathrm{S} \\
\text { 3 months }\end{array}$ & $\begin{array}{c}\mathrm{M} \pm \mathrm{S} \\
6 \text { months }\end{array}$ & $\begin{array}{c}\text { P } \\
\text { Before - } 3 \text { months }\end{array}$ & $\begin{array}{c}\text { P } \\
\text { Before }-6 \text { months }\end{array}$ \\
\hline IA & $4,08 \pm 0,24$ & $3,72 \pm 0,14$ & $3,41 \pm 0,15$ & 0,1510 & $<0,0001$ \\
\hline IIA & $4,07 \pm 0,26$ & $3,83 \pm 0,16$ & $3,53 \pm 0,17$ & 0,1947 & $<0,0001$ \\
\hline IIIA & $4,05 \pm 0,26$ & $3,81 \pm 0,12$ & $3,62 \pm 0,16$ & 0,2759 & $<0,0001$ \\
\hline IVA & $4,09 \pm 0,34$ & $3,93 \pm 0,14$ & $3,73 \pm 0,25$ & 0,4101 & 0,0005 \\
\hline VA & $4,08 \pm 0,32$ & $3,99 \pm 0,17$ & $3,85 \pm 0,21$ & 0,7615 & 0,0655 \\
\hline IB & $4,27 \pm 0,28$ & $3,84 \pm 0,12$ & $3,64 \pm 0,17$ & 0,3417 & $<0,0001$ \\
\hline IIB & $4,25 \pm 0,30$ & $4,01 \pm 0,14$ & $3,79 \pm 0,14$ & 0,2306 & $<0,0001$ \\
\hline IIIB & $4,28 \pm 0,29$ & $3,94 \pm 0,12$ & $3,82 \pm 0,15$ & 0,1644 & $<0,0001$ \\
\hline IVB & $4,24 \pm 0,22$ & $4,04 \pm 0,16$ & $3,94 \pm 0,21$ & 0,3787 & $<0,0001$ \\
\hline VB & $4,28 \pm 0,30$ & $4,17 \pm 0,14$ & $4,08 \pm 0,26$ & 0,6838 & 0,0591 \\
\hline
\end{tabular}


Berikhanova RR (2020) The role of non-drug strategies in reducing the risk of cardiovascular complications in women with metabolic syndrome during the menopausal transition

CRP significantly decreased by $8,8 \%$ ( $\mathrm{p}=0,0455)$, but it was significantly higher against subgroup IA. In subgroup VB, the decrease in CRP was $7,6 \%$, but it was not statistically significant $(\mathrm{p}=0,1637)$ and significantly differed from subgroups IB, IIB and IIIB, in which physiotherapy was used.

Carbohydrate and fat metabolism: The dynamics of the HOMAIR level is shown in table 12. Regression of the HOMA-IR level in subgroup IA was significant after 3 months of treatment, amounting to $25,0 \%(\mathrm{p}=0,0496)$, reaching $54,2 \%(\mathrm{p}<0,0001)$ after 6 months of therapy. After 6 months of treatment, a significant decrease was observed in subgroups IIA, IIIA and IVA: 49,3\% ( $<<0,0001), 49,7 \%(\mathrm{p}<0,0001)$ and $38,7 \%(\mathrm{p}<0,0001)$ of the baseline level, respectively. After 6 months of treatment in subgroups A of groups I, II, and III (using physical therapy), HOMA-IR returned to normal values. It should be noted that the HOMA-IR index did not differ significantly between these subgroups, but after 6 months of treatment it was significantly higher in subgroup A of group IV (in which physiotherapy was not used) against these groups. HOMA-IR index significantly decreased after 3 months of treatment only in the subgroup IB of $22,9 \%(p=0,0430)$, and after 6 months of treatment a statically significant decline was demonstrated together with the subgroup IB subgroup IIB, IIIB and IVB in subgroup IB is $50,5 \%(p<0,0001)$ in subgroup IIB by $36,8 \%(p<0,0001)$ in a subgroup IIIB $37,2 \%(p<0,0001)$ in subgroup IVB $32,0 \%(p<0,0001)$. However, among patients with moderate MPS only in subgroup IB, the HOMA-IR index reached normal values by the sixth month of treatment $(2,68 \pm 0,20)$. At the same time, the level of HOMA-IR after 6 months of treatment in both subgroups of group $\mathrm{V}$ did not significantly change and was significantly higher compared to the other groups.

The study of the lipidogram showed that the regression of the AI occurred due to a decrease in the atherogenic fractions of lipids (mainly triglycerides). The decrease in AI was significant in both subgroups of all study groups after 6 months of treatment (Table 13). However, this indicator decreased most significantly when using therapeutic complexes that include physical therapy: in subgroup IA after 3 months of treatment by $13,6 \%(\mathrm{p}=0,3679)$, after 6 months of treatment by $31,2 \%$ $(\mathrm{p}<0,0001)$, respectively in subgroup IIA - by $12,6 \%(\mathrm{p}=0,2480)$ and $26,5 \%(\mathrm{p}=0,0002)$, in subgroup IIIA - by $12,7 \%(\mathrm{p}=0,4013)$ and $28,8 \%$ ( $\mathrm{p}<0,0001)$, differences between subgroups were not reliable. Regression of AI in the IVA subgroup after 3 months of treatment was $10,4 \%$ ( $\mathrm{p}=0,1292)$, after 6 months $22,3 \%(\mathrm{p}=0,0001)$, in the VA subgroup $7,6 \%$ $(\mathrm{p}=0,2502)$ and $17,0 \%(\mathrm{p}=0,0007)$ respectively, while the AI values in the VA subgroup were significantly higher in comparison with the IA, IIA and IIIA subgroups. Among subgroups of women with moderate MPS, the most pronounced positive transformation of the lipid profile was observed in subgroup IB, which was expressed in a decrease in IA after 3 months of treatment by $14,7 \%(p=0,0993)$, after 6 months of treatment by $30,5 \%(p<0,0001)$. The decrease in AI in subgroup IIB was $7,9 \%$ and $25,1 \%$ respectively, in subgroup IIIB $11,3 \%(p=0,8010)$ and $27,8 \%(p=0,0003)$, in subgroup IVB $6,7 \%(p=0,9110)$ and $21,0 \%$ $(\mathrm{p}=0,0010)$, in subgroup VB it decreased the least significantly - by $4,6 \%$ $(p=0,7072)$ and $10,9 \%(p=0,0327)$. In subgroup VB AI was significantly higher in comparison points against subgroup IB.

Green's Test: The total score on the green's climacteric scale in dynamics is shown in table 14 . The initial average score in subgroups A was $10,59 \pm 1,06$ points, in subgroups $b 18,55 \pm 1,34$ points. A strong correlation was found between the HOMA-IR index and the overall score of the green climacteric scale $(r=0,86 ; p<0.005)$, between BMI and the overall score of the green climacteric scale $(r=0,78 ; p<0,005)$. Among patients with mild MPS, regression of climacteric symptoms was detected after 3 months of treatment in subgroup IA by $25,5 \%$ ( $\mathrm{p}=0,1419)$, in subgroup IIA by $20,8 \%(\mathrm{p}=0,1324)$, in subgroup IIIA by $18,6 \%(\mathrm{p}=0,0867)$, in subgroup IVA by $14,3 \%(\mathrm{p}=0,0737)$, but it was not reliable. After 6 months of treatment, a statistically significant decrease was found in these subgroups by $55,3 \%(\mathrm{p}<0,0001), 44,6 \%(\mathrm{p}<0,0001)$,

Table 11. Dynamics of the level of C-reactive protein, $\mathrm{mg} / 1(0-5,0 \mathrm{mg} / \mathrm{l})$

\begin{tabular}{|c|c|c|c|c|c|}
\hline Subgroup & $\begin{array}{l}\mathrm{M} \pm \mathrm{S} \\
\text { Before }\end{array}$ & $\begin{array}{c}\mathrm{M} \pm \mathrm{S} \\
3 \text { months }\end{array}$ & $\begin{array}{c}\mathrm{M} \pm \mathrm{S} \\
6 \text { months }\end{array}$ & $\begin{array}{c}\text { P } \\
\text { Before - } 3 \text { months }\end{array}$ & $\begin{array}{c}\text { P } \\
\text { Before }-6 \text { months }\end{array}$ \\
\hline IA & $4,44 \pm 0,42$ & $3,88 \pm 0,28$ & $3,63 \pm 0,29$ & 0,0713 & $<0,0001$ \\
\hline IIA & $4,38 \pm 0,40$ & $4,05 \pm 0,35$ & $3,75 \pm 0,36$ & 0,3797 & 0,0014 \\
\hline IIIA & $4,44 \pm 0,41$ & $4,02 \pm 0,33$ & $3,81 \pm 0,34$ & 0,1076 & 0,0038 \\
\hline IVA & $4,36 \pm 0,40$ & $4,15 \pm 0,37$ & $3,96 \pm 0,41$ & 0,5751 & 0,0089 \\
\hline VA & $4,41 \pm 0,34$ & $4,19 \pm 0,31$ & $4,02 \pm 0,39$ & 0,2812 & 0,0455 \\
\hline IB & $4,45 \pm 0,50$ & $3,89 \pm 0,23$ & $3,66 \pm 0,29$ & 0,1953 & 0,0008 \\
\hline IIB & $4,45 \pm 0,47$ & $4,05 \pm 0,29$ & $3,73 \pm 0,28$ & 0,0912 & 0,0001 \\
\hline IIIB & $4,46 \pm 0,45$ & $4,07 \pm 0,36$ & $3,78 \pm 0,41$ & 0,2627 & 0,0048 \\
\hline IVB & $4,44 \pm 0,48$ & $4,16 \pm 0,28$ & $4,00 \pm 0,39$ & 0,2576 & 0,0066 \\
\hline VB & $4,48 \pm 0,46$ & $4,30 \pm 0,32$ & $4,14 \pm 0,40$ & 0,7753 & 0,1637 \\
\hline
\end{tabular}

Table 12. Dynamics of the HOMA-IR level (norm $<2,7$ )

\begin{tabular}{|c|c|c|c|c|c|}
\hline Subgroup & $\begin{array}{l}\mathrm{M} \pm \mathrm{S} \\
\text { Before }\end{array}$ & $\begin{array}{c}\mathrm{M} \pm \mathrm{S} \\
3 \text { months }\end{array}$ & $\begin{array}{c}\mathrm{M} \pm \mathrm{S} \\
6 \text { months }\end{array}$ & $\begin{array}{c}\text { P } \\
\text { Before - } 3 \text { months }\end{array}$ & $\begin{array}{c}\text { P } \\
\text { Before }-6 \text { months }\end{array}$ \\
\hline IA & $5,15 \pm 0,70$ & $3,86 \pm 0,76$ & $2,36 \pm 0,21$ & 0,0496 & $<0,0001$ \\
\hline IIA & $4,99 \pm 0,79$ & $4,01 \pm 0,69$ & $2,53 \pm 0,21$ & 0,2883 & $<0,0001$ \\
\hline IIIA & $5,11 \pm 0,70$ & $4,03 \pm 0,86$ & $2,57 \pm 0,21$ & 0,4013 & $<0,0001$ \\
\hline IVA & $5,06 \pm 0,77$ & $4,43 \pm 0,68$ & $3,10 \pm 0,51$ & 0,5264 & $<0,0001$ \\
\hline VA & $4,98 \pm 0,64$ & $4,58 \pm 0,77$ & $4,21 \pm 1,19$ & 0,9992 & 0,2990 \\
\hline IB & $5,41 \pm 0,84$ & $4,17 \pm 0,68$ & $2,68 \pm 0,20$ & 0,0430 & $<0,0001$ \\
\hline IIB & $5,38 \pm 0,57$ & $4,65 \pm 0,78$ & $3,40 \pm 0,57$ & 0,1635 & $<0,0001$ \\
\hline IIIB & $5,43 \pm 0,80$ & $4,64 \pm 0,69$ & $3,41 \pm 0,51$ & 0,1510 & $<0,0001$ \\
\hline IVB & $5,38 \pm 0,79$ & $4,87 \pm 0,85$ & $3,66 \pm 0,90$ & 0,6749 & $<0,0001$ \\
\hline VB & $5,34 \pm 0,61$ & $5,04 \pm 0,60$ & $4,74 \pm 0,83$ & 0,5166 & 0,2340 \\
\hline
\end{tabular}


Berikhanova RR (2020) The role of non-drug strategies in reducing the risk of cardiovascular complications in women with metabolic syndrome during the menopausal transition

Table 13. Dynamics of the level of the atherogenicity index $(<3)$

\begin{tabular}{|c|c|c|c|c|}
\hline Subgroup & $\begin{array}{c}\mathbf{M} \pm \mathbf{S}, \\
\text { Before }\end{array}$ & $\begin{array}{c}\mathbf{M} \pm \mathbf{S}, \\
\mathbf{3} \text { months }\end{array}$ & $\begin{array}{c}\mathbf{M} \pm \mathbf{S}, \\
\mathbf{6} \text { months }\end{array}$ & $\begin{array}{c}\mathbf{P} \\
\text { Before }-\mathbf{6} \text { months }\end{array}$ \\
\hline IA & $3,35 \pm 0,59$ & $2,90 \pm 0,31$ & $2,31 \pm 0,29$ & 0,3679 \\
\hline IIA & $3,43 \pm 0,52$ & $3,00 \pm 0,35$ & $2,52 \pm 0,32$ & 0,2480 \\
\hline IIIA & $3,48 \pm 0,49$ & $3,04 \pm 0,37$ & $2,47 \pm 0,26$ & 0,4013 \\
\hline IVA & $3,55 \pm 0,44$ & $3,18 \pm 0,35$ & $2,76 \pm 0,36$ & 0,1292 \\
\hline VA & $3,47 \pm 0,29$ & $3,20 \pm 0,29$ & $2,88 \pm 0,40$ & 0,2502 \\
\hline IB & $3,35 \pm 0,35$ & $2,86 \pm 0,31$ & $2,33 \pm 0,17$ & 0,0993 \\
\hline IIB & $3,24 \pm 0,45$ & $2,98 \pm 0,33$ & $2,43 \pm 0,29$ & 0,0001 \\
\hline IIIB & $3,47 \pm 0,51$ & $3,08 \pm 0,36$ & $2,51 \pm 0,35$ & \\
\hline IVB & $3,40 \pm 0,41$ & $3,17 \pm 0,31$ & 0,0001 \\
\hline VB & $3,38 \pm 0,39$ & $3,22 \pm 0,35$ & 0,0001 \\
\hline
\end{tabular}

Table 14. Severity of symptoms of climacteric syndrome on the green scale, points

\begin{tabular}{|c|c|c|c|c|}
\hline Subgroup & $\begin{array}{c}\mathbf{M} \pm \mathbf{S} \\
\text { Before }\end{array}$ & $\begin{array}{c}\mathbf{M} \pm \mathbf{S}, \\
\mathbf{3} \text { months }\end{array}$ & $\begin{array}{c}\mathbf{M} \pm \mathbf{S}, \\
\mathbf{6} \text { months }\end{array}$ & $\begin{array}{c}\mathbf{P} \\
\text { Before }-\mathbf{6} \text { months }\end{array}$ \\
\hline IA & $11,00 \pm 1,05$ & $8,19 \pm 1,16$ & $4,91 \pm 0,70$ & 0,1419 \\
\hline IIA & $10,61 \pm 1,10$ & $8,40 \pm 1,40$ & $5,88 \pm 0,87$ & 0,1324 \\
\hline IIIA & $10,40 \pm 1,08$ & $8,47 \pm 1,14$ & $6,20 \pm 1,13$ & 0,0867 \\
\hline IVA & $10,31 \pm 0,99$ & $8,83 \pm 1,08$ & $7,42 \pm 1,03$ & 0,0737 \\
\hline VA & $10,61 \pm 1,09$ & $11,95 \pm 1,36$ & $12,43 \pm 1,08$ & 0,0286 \\
\hline IB & $18,68 \pm 1,27$ & $14,17 \pm 1,22$ & $10,96 \pm 1,25$ & 0,1219 \\
\hline IIB & $18,83 \pm 1,49$ & $16,80 \pm 1,04$ & $14,75 \pm 1,43$ & \\
\hline IIIB & $18,36 \pm 1,28$ & $16,95 \pm 1,53$ & $14,86 \pm 1,10$ & \\
\hline IVB & $18,21 \pm 1,39$ & $17,34 \pm 1,53$ & 16,0001 & \\
\hline VB & $18,65 \pm 1,29$ & $19,34 \pm 1,19$ & $<, 0001$ \\
\hline
\end{tabular}

$40,4 \%(\mathrm{p}<0,0001)$ and $28,1 \%(\mathrm{p}=0,0007)$, respectively. Among patients with moderate MPS, the total score of climacteric disorders decreased after 3 months of treatment in subgroup IB by $24,1 \%(\mathrm{p}=0,1219)$, in subgroup IIB by $10,8 \%(p=0,22229)$, in subgroup IIIB by $7,7 \%$ ( $\mathrm{p}=0,2203)$, in subgroup IVB by $4,8 \%(\mathrm{p}=0,1996)$, but the differences were not significant in comparison with the initial values. After 6 months of treatment, the regression rate was $39,9 \%(\mathrm{p}<0,0001), 19,7 \%$ $(\mathrm{p}<0,0001), 14,5 \%(\mathrm{p}<0,0001)$ and $6,9 \%(\mathrm{p}=0,0041)$, respectively. In subgroups IIB, IIIB, and IVB, the total score on the green scale was significantly higher compared to subgroup IB. It is important to note a significant increase in climacteric disorders in group $\mathrm{V}$, which was expressed in an increase in the total test score in subgroup VA after 3 months of treatment by $12,6 \%(p=0,0286)$, after 6 months of treatment by $17,1 \%(p=0,0006)$, and in subgroup VB after 6 months of treatment by $7,6 \%(\mathrm{p}=0,0106)$.

Against the background of treatment, the endometrium, cervical epithelium, breast tissue were not compromised, which allowed us to state the safety of the programs used. High compliance to treatment was noted.

\section{Discussion}

In women with MPS and MS, the improvement in the functioning of the hypothalamic-pituitary-ovarian system, indicators of carbohydrate, fat metabolism, hemostasis, regression of the severity of metabolic inflammation and the weakening of subjective climacteric symptoms against the background of a decrease in BMI are more pronounced when using complexes in which, in addition to lifestyle modification, physical therapy, balneotherapy and physiotherapy were included. In patients with moderate MPS, optimal correction of metabolic and endocrine disorders required the use of a whole range of synergistic physiotherapy factors (vibrotherapy, chromotherapy, melotherapy, aromatherapy, aeroionotherapy). Taking into account the focus on comorbid pathology and the similarity of pathogenetic mechanisms of MS and MPS, the therapeutic strategy is based on lifestyle modification $[27,28]$. Physical therapy promoted the activation of metabolism by reducing adipose tissue and increasing muscle tissue [29,30]. Improvement of the studied parameters was favored by the use of drinking balneotherapy due to the coordination of enteroinsular interactions and a decrease in IR $[31,32]$. The inclusion of vitamins and minerals in the therapeutic program is based on their antioxidant abilities and their importance in coordinating metabolic processes $[33,34]$. Music therapy has made adjustments to the state of the psychoemotional sphere by pulsating stimulation of the auditory receptors, limbic system, metabolism, and normalization of the respiratory and cardiovascular systems [35]. Aromatherapy had anti-stress, anti-inflammatory effects, normalized the activity of the endocrine system by affecting the olfactory sensory system and modulating the activity of the limbic complex, pituitaryadrenal system [36-38]. Aeroionization harmonized the work of the relationship's nervous system through a neurohumoral mechanism [39-40]. The inclusion of vibrotherapy in the treatment complex was justified by its ability to improve blood circulation, activate redox processes, and provide anti-inflammatory and analgesic effects by stimulating the receptors with mechanical vibrations [41,42]. The result of photobiomodulating effects of chromotherapy was the restoration of the balance of sympathetic-parasympathetic relationships, antistress effect $[43,44]$. It is important to note that stress is currently regarded as an independent risk factor for atherosclerosis and fatal cardiovascular complications with corresponding metabolic, inflammatory and hemostatic disorders $[45,46]$.

\section{Conclusion}

The combined effects of physical therapy, vitamins and minerals, and polymodal physical factors on the background of lifestyle modification contribute to the normalization of the hypothalamic-pituitaryovarian system, improving carbohydrate and fat metabolism, reducing 
Berikhanova RR (2020) The role of non-drug strategies in reducing the risk of cardiovascular complications in women with metabolic syndrome during the menopausal transition

metabolic inflammation, prothrombogenic potential of the blood, and, consequently, reducing cardiovascular risk in parallel with the regression of menopausal disorders in patients with MPS complicated by MS. In patients with moderate MPS, the program with simultaneous use of vibrotherapy, chromotherapy, melotherapy, aromatherapy, and aeroionotherapy has an advantage. It seems promising to use non-drug programs as additional measures in the curation of women with severe menopausal syndrome. However, further research is needed to explore the possibilities of non-drug therapeutic strategies in older women with comorbid pathology.

\section{References}

1. Yazdkhasti M, Negarandeh R, Behboodi Moghadam Z (2019) An empowerment model of Iranian women for the management of menopause: A grounded theory study. Int $J$ Qual Stud Health Well-being 14:1665958. [Crossref]

2. Harris MT (2013) Menopause: The need for a paradigm shift from disease to women's health.

3. Zając-Gawlak I, Kłapcińska B, Kroemeke A, Pośpiech D, Pelclová J, et al. (2017) Associations of visceral fat area and physical activity levels with the risk of metabolic syndrome in postmenopausal women. Biogerontology 18: 357-366. [Crossref]

4. Muthuvel J, Robert DL, Brian DL, Kent RB, Whyte GO, et al. (2011) Alterations in platelet function and cell-derived microvesicles in recently menopausal women: Relationship to metabolic syndrome and atherogenic risk. $J$ Cardiovasc Transl Res 4 : 811-822. [Crossref]

5. Uygur MM, Yoldemir T, Yavuz DG (2018) Thyroid disease in the perimenopause and postmenopause period. Climacteric 21: 542-548. [Crossref]

6. Gietka-Czernel M (2017) The thyroid gland in postmenopausal women: Physiology and diseases. Prz Menopauzalny 16: 33-37. [Crossref]

7. Proietto J (2017) Obesity and weight management at menopause. Aust Fam Physician 46: 368-370. [Crossref]

8. Al-Safi ZA, Polotsky AJ (2015) Obesity and menopause. Best Pract Res Clin Obstet Gynaecol 29: 548-553.

9. Grandl G, Wolfrum C (2018) Hemostasis, endothelial stress, inflammation, and the metabolic syndrome. Semin Immunopathol 40: 215-224.

10. Lizcano F, Guzmán G (2014) Estrogen deficiency and the origin of obesity during menopause. Biomed Res Int 2014: 757461. [Crossref]

11. Chedraui P, Pérez-López FR (2019) Metabolic syndrome during female midlife: What are the risks? Climacteric 22: 127-132. [Crossref]

12. Willem van den B, Jolanda van B, Kanita S, Femke PMH, Lars V, et al. (2019) Current and future nutritional strategies to modulate inflammatory dynamics in metabolic disorders. Front Nutr 6: 129. [Crossref]

13. Stolarczyk E (2017) Adipose tissue inflammation in obesity: A metabolic or immune response? Curr Opin Pharmacol 37: 35-40. [Crossref]

14. Saltiel AR, Olefsky JM (2017) Inflammatory mechanisms linking obesity and metabolic disease. J Clin Invest 127: 1-4. [Crossref]

15. Grandl G, Wolfrum C (2018) Hemostasis, endothelial stress, inflammation, and the metabolic syndrome. Semin Immunopathol 40: 215-224. [Crossref]

16. Wasserman DH, Wang TJ, Brown NJ (2018) The vasculature in prediabetes. Circ Res 122: 1135-1150. [Crossref]

17. Cengiz H, Kaya C, Suzen Caypinar S, Alay I (2019) The relationship between menopausal symptoms and metabolic syndrome in postmenopausal women. $J$ Obstet Gynaecol 39: 529-533. [Crossref]

18. Lee SW, Jo HH, Kim MR, Kwon DJ, You YO, et al. (2012) Association between menopausal symptoms and metabolic syndrome in postmenopausal women. Arch Gynecol Obstet 285: 541-548. [Crossref]

19. The 2017 hormone therapy position statement of The North American Menopause Society. Menopause 25: 1362-1387.

20. Marjoribanks J, Farquhar C, Roberts H, Lethaby A, Lee J (2017) Long-term hormone therapy for perimenopausal and postmenopausal women. Cochrane Database Syst Rev 1: CD004143. [Crossref]

21. McNeil M (2017) Menopausal hormone therapy: Understanding long-term risks and benefits. JAMA 318: 911-913.
22. Mudhune GH, Armour M, McBride KA (2019) Safety of menopausal hormone therapy in breast cancer survivors older than fifty at diagnosis: A systematic review and metaanalysis. Breast 47: 43-55. [Crossref]

23. Naftolin F, Friedenthal J, Nachtigall R, Nachtigall L (2019) Cardiovascular health and the menopausal woman: the role of estrogen and when to begin and end hormone treatment. Faculty Rev: 1576. [Crossref]

24. Greene JG (1998) Constructing a standard climacteric scale. Maturitas 29: 25-31 [Crossref]

25. Recommendations of experts of the All-Russian Scientific Society of Cardiology on the diagnosis and treatment of metabolic syndrome (second revision). Practical medicine 5: 81-101.

26. Kegel AH (1952) Sexual functions of the pubococcygeus muscle. West J Surg Obstet Gynecol 60: 521-524. [Crossref]

27. 2016 European guidelines on cardiovascular disease prevention in clinical practice.

28. The 2017 hormone therapy position statement of The North American Menopause Society. Menopause 25: 1362-1387. [Crossref]

29. Myers J, Kokkinos P, Nyelin E (2019) Physical activity, cardiorespiratory fitness, and the metabolic syndrome. Nutrients 11:1652. [Crossref]

30. Mauro V, Veronica P, Daniela M, Arianna G, Paola S, et al. (2020) Sex/Gender-specific imbalance in CVD: Could physical activity help to improve clinical outcome targeting cvd molecular mechanisms in women? Int J Mol Sci 21: 1477. [Crossref]

31. Naumann J, Biehler D, Lüty T, Sadaghiani C (2017) Prevention and Therapy of Type 2 Diabetes-What Is the Potential of Daily Water Intake and Its Mineral Nutrients? Nutrients 9: 914. [Crossref]

32. Toxqui L (2016) An intervention with mineral water decreases cardiometabolic risk biomarkers. a crossover, randomised, controlled trial with two mineral waters in moderately hypercholesterolaemic adults. Nutrients 8: 3400. [Crossref]

33. Jamilian M, Sabzevar NK, Asemi Z (2019) The effect of magnesium and vitamin e cosupplementation on glycemic control and markers of cardio-metabolic risk in women with polycystic ovary syndrome: A randomized, double-blind, placebo-controlled trial Horm Metab Res 51: 100-105. [Crossref]

34. Ko SH, Kim HS (2020) Menopause-associated lipid metabolic disorders and foods beneficial for postmenopausal women. Nutrients 12: 202. [Crossref]

35. Montinari MR, Giardina S, Minelli P, Minelli S (2018) History of music therapy and its contemporary applications in cardiovascular diseases. South Med J 111: 98-102. [Crossref]

36. Nasibeh R, Masumeh G, Talat K, Leila K, Fatemeh Rajab D, et al. (2019) Effect of lavender on sleep, sexual desire, vasomotor, psychological and physical symptom among menopausal and elderly women: A systematic review. $J$ Menopausal Med 25: 88-93. [Crossref]

37. Roya N, Rafat K, Firoozeh A, Razzag F, Farideh M, et al. (2018) The effect of lavender aromatherapy on the symptoms of menopause. J Natl Med Assoc 110: 265-269. [Crossref]

38. Schneider R, Singer N, Singer T (2019) Medical aromatherapy revisited-Basic mechanisms, critique, and a new development. Hum Psychopharmacol 34: 2683. [Crossref]

39. Iwama H (2004) Negative air ions created by water shearing improve erythrocyte deformability and aerobic metabolism. Indoor Air 14: 293-297. [Crossref]

40. Chien-Heng C, Su-Ru C, Chih-Han W, Yung-Chao C, Yu-Min C, et al. (2019) The effects of negative air ions on cognitive function: an event-related potential (ERP) study. Int J Biometeorol 63: 1309-1317. [Crossref]

41. Schneider R (2018) Effectiveness of myofascial trigger point therapy in chronic back pain patients is considerably increased when combined with a new, integrated, lowfrequency shock wave vibrotherapy (Cellconnect Impulse): A two-armed, measurement repeated, randomized, controlled pragmatic trial. J Back Musculoskelet Rehabil 31: 5764. [Crossref]

42. Matteo Z, Paolo C, Cristina F, Marco T, Manuela G (2018) Whole-body vibration training in obese subjects: A systematic review. PLoS One 2018; 13: 0202866. [Crossref]

43. Paragas ED Jr, Ng ATY, Reyes DVL, Reyes GAB (2019) Effects of chromotherapy on the cognitive ability of older adults: A quasi-experimental study. Explore (NY) 15: 191-197. [Crossref]

44. Samina T Yousuf A, Hafiz MR, Iram I, Syeda Rabab K, Ameena A (2019) The mechanistic basis of chromotherapy: Current knowledge and future perspectives. Complement Ther Med 46: 217-222. [Crossref] 
Berikhanova RR (2020) The role of non-drug strategies in reducing the risk of cardiovascular complications in women with metabolic syndrome during the menopausal transition

45. Chinnaiyan KM (2019) Role of stress management for cardiovascular disease prevention. Curr Opin Cardiol 34: 531-535. [Crossref]
46. Kivimäki M, Steptoe A (2018) Effects of stress on the development and progression of cardiovascular disease. Nat Rev Cardiol 15: 215-229. [Crossref]

Copyright: 2020 Berikhanova RR. This is an open-access article distributed under the terms of the Creative Commons Attribution License, which permits unrestricted use, distribution, and reproduction in any medium, provided the original author and source are credited. 